\title{
The Role of the Introductory Matter in Bilingual Dictionaries of English and Arabic
}

\author{
Hashan Al-Ajmi, Department of English, Kuwait University, Kuwait \\ (hashan98@yahoo.com)
}

\begin{abstract}
Monolingual and bilingual dictionaries for learners of English as foreign language differ from each other in many aspects. Among the differences are the types of information a dictionary provides outside the $\mathrm{A}-\mathrm{Z}$ word list, especially in its introductory matter. Yet, dictionary introductions have been referred to rather peripherally in the literature on dictionary users and uses. Within the context of lexicographic practice, this study aims to outline the differences between EFL learner's dictionaries and bilingual English-Arabic dictionaries, and to determine to what extent a given set of popular dictionaries provide varied and sufficient information in their introductions. Three categories of dictionaries will be the subject of comparison: EFL dictionaries, European bilingual dictionaries, and bilingual dictionaries in the Arab world.
\end{abstract}

Keywords: BILINGUAL DICTIONARY, INTRODUCTORY MATTER, ENGLISH-ARABIC, EFL LEARNER'S DICTIONARY, ORIENTALIST DICTIONARY

Opsomming: Die rol van die inleidende gedeelte in tweetalige woordeboeke van Engels en Arabies. Eentalige en tweetalige woordeboeke vir aanleerders van Engels as vreemde taal verskil in baie opsigte van mekaar. Een van die verskille is die tipes inligting wat ' $n$ woordeboek buite die A-Z-woordelys verskaf, veral in die inleidende gedeelte. Tog is daar slegs in die verbygaan na woordeboekinleidings in die literatuur oor woordeboekgebruikers en -gebruik verwys. Hierdie studie het dit ten doel om, binne die konteks van die leksikografiese praktyk, die verskille uit te stippel tussen EVT-aanleerderswoordeboeke en tweetalige Engels-Arabiese woordeboeke, en te bepaal in watter mate ' $n$ gegewe groep gewilde woordeboeke veelsoortige en genoegsame inligting in hul inleidings verskaf. Drie kategorieë woordeboeke sal die onderwerp van hierdie vergelyking vorm: EVT-woordeboeke, Europese tweetalige woordeboeke en tweetalige woordeboeke binne die Arabiese wêreld.

Sleutelwoorde: TWEETALIGE WOORDEBOEK, INLEIDENDE GEDEELTE, ENGELSARABIES, EVT-AANLEERDERSWOORDEBOEK, ORIËNTALISTEWOORDEBOEK

\section{Introduction}

A dictionary introduction is widely regarded in lexicographic circles as an essential source of information in all types of dictionaries. It should be noted, however, that a terminological disagreement exists in this regard; some diction- 
aries use the term "introduction" while others begin their texts with the title "preface". Still, many lexicographers refer to the pages where the dictionary's microstructure and macrostructure are described as the "introductory matter". Here, one has to differentiate between an introduction in a book and one in a dictionary. An introduction or preface in a book aims to provide its readers with a general overview and prepare them for a series of related ideas in numerically ordered chapters. On the other hand, because a dictionary is a collection of different articles sharing nothing in common except the structure and organization of information, a dictionary introduction performs a different function. It limits itself to explaining this structure and addressing issues such as the symbols, abbreviations and cross-reference system used in the dictionary.

From a user perspective, one can determine the effectiveness of an introduction according to the extent to which it addresses the dictionary user's needs in relation to the information retrieval process. It may be of greater importance when a user is new to dictionary look-up operations but it loses its significance gradually as he/she becomes more familiar with the dictionary's conventions, mostly through trial and error. Indeed, it has been found that only a small percentage of dictionary users refer to their dictionary introductions for help. Béjoint (1981), for example, found that French advanced learners using EFL dictionaries rarely utilized the information contained in their dictionary guides.

It should also be noted that lexicographic studies have so far dealt with dictionary introductions in a peripheral fashion, the emphasis being traditionally placed on the components of the entry: morphology of words, meanings, pronunciation and syntactic structures. Yet a bilingual dictionary is, after all, a practical tool used in an intellectual activity such as reading, writing, or translating from or into a foreign language. Accordingly, there is an obvious need for lexicographers to pay attention to those aspects related to the user's capability of accessing the required dictionary information. This can be achieved by a lexicographic re-examination of the role of the introduction to ensure that it provides simplified and sufficient information that may lead to profitable use of the dictionary.

Despite the rare reference to dictionary introductions in lexicographic literature, one can classify lexicographers' opinions in this connection into three approaches. Some believe that it is the duty of the dictionary maker to provide the users with all the information they need at the point of entry, because these users rarely refer to their dictionary introductions (Gimson 1973, Stein 1984, Wiegand 1984, Berkov 1990). Another group of lexicographers indicate that many language learners come to the foreign-language learning setting without any background in the use of mother-tongue dictionaries and that there is a need to encourage users to read dictionary introductions and to train them in how to find the required information through a division of work between the dictionary and foreign-language textbooks (Rossner 1985, Crystal 1986, Cowie 
1987, Snell-Hornby 1987). A third view is expressed by Hartmann (1986, 1987) who says that training in dictionary use is primarily the teacher's responsibility not the dictionary's, because, although dictionary guides set out a number of possible uses of a dictionary, these are based not on an analysis of the reference needs of the learner, but on the various information categories that the dictionary is traditionally expected to contain, i.e. meaning, spelling, grammar, etymology and pronunciation.

The problem that arises when one tries to inculcate users with reference skills, is that dictionaries, especially those designed for foreign learners of English, are now developing more rapidly than before, thus widening the gap that already exists between the complexity of information and the users' often rudimentary reference skills (Cowie 1987).

An introduction usually addresses certain categories of dictionary information such as the dictionary macro- and microstructure. Yet introductions vary in the way they treat this information. Some concentrate on certain aspects of the entry and ignore others, whereas other introductions may not specify the intended user category, probably because of factors relating to distribution. Also, compilers do not follow standardized and clear criteria in writing an introduction or dividing it into sections. Therefore, many monolingual and bilingual dictionaries contain very long introductions which are not easy to read and their excessive length and use of specialized linguistic terms would represent a burden on the user who tries to find a specific point of guidance.

According to Stein (1989), an introduction performs different functions. She indicates that it publicizes the dictionary: it may include claims of superiority over similar dictionaries, and at the same time it provides invaluable information on the content and structure of the dictionary. She also points out that the amount of information provided in the introduction about the lexicographic team, the accuracy of description and transparency, gives an indication of their expertise and attitude towards the user. In some dictionaries, the introduction serves as a lesson in lexicography due to accuracy of description and clarity with regard to lexicographic policies. On the other hand, Stein observes that other dictionaries do not clarify some points which are essential for understanding the structure of the dictionary. In addition, an introduction may be an important source of information on the policies followed by compilers of old dictionaries and the cultural circumstances that had a role in the making of these dictionaries.

\section{Aims of the study}

The present study aims to outline the following :

(a) Similarities and differences between bilingual and EFL dictionaries in the area of dictionary introductions as well as recent developments regarding this aspect in both types of dictionaries. 
(b) The extent to which these dictionary introductions provide users with varied, accurate and sufficient information about these dictionaries.

In order to specify similarities and differences between introductions of bilingual and EFL dictionaries in addition to recent developments, the present study will analyze, compare and criticize the introductory matter in a set of eight dictionaries classified into three categories:

(a) European bilingual dictionary: Collins-Robert (French-English/EnglishFrench);

(b) Bilingual dictionaries of Arabic and English:

(i) Bilingual dictionaries compiled by Orientalists: Dictionary of Modern Written Arabic (Arabic-English), Wortabet (Arabic-English), Learner's Dictionary (Arabic-English),

(ii) Bilingual dictionaries compiled by Arab lexicographers: Elias' Modern Dictionary (Arabic-English), School Dictionary (Arabic-English/English-Arabic), Al-Mawrid (English-Arabic);

(c) EFL dictionary: Oxford Advanced Learners' Dictionary.

The similarities and differences will be determined by a classification of information categories in the introductions to these dictionaries. Given the wide scope of the subject, the analysis will focus on the first three of the following categories:

(a) Specification of the intended group of users,

(b) Indication of the reasons for compiling the dictionary,

(c) Reference to the sources of the dictionary,

(d) Outline of new features in the dictionary,

(e) Specification of the number of entries (or words),

(f) Practical guidance.

\subsection{Specifying the intended group of users}

Monolingual and bilingual dictionaries designed for foreign learners of English differ in their content and presentation of information. This is due to the fact that a monolingual EFL dictionary addresses users coming from different cultures whereas the bilingual dictionary is written for a specific linguistic community (Atkins 1985). Lexicographers have agreed on the need to specify a user group such as learners, speakers of the source language or speakers of the tar- 
get language, and the impossibility to cater for the needs of all these groups in a single dictionary (Householder and Saporta 1962).

A close examination of the introduction to the Oxford Advanced Learners' Dictionary $(O A L D)$ shows a clear reference to the foreign learner's needs in both reading and writing. Reference to learners is also made in the bilingual dictionary Collins-Robert, where the introduction claims that the dictionary aims to provide the user with the highest standards of proficiency coupled with ease of use and help in areas that cause difficulties to the learner. The introduction also emphasizes its pedagogical role by indicating that one of the important steps for successful language learning is the proper use of a good dictionary. It also addresses the two skills of reading and writing by saying that "this dictionary is indispensable in understanding and self-expression in French".

As for Orientalists' bilingual dictionaries these have been designed to meet the reference needs of Orientalists and students of Arabic in the West. However, the introductions in these dictionaries vary in the extent of accuracy in their reference to the intended user categories. For example, the introduction in Wortabet's dictionary does not specify one category of users but several: "This dictionary is indispensable for students, translators or intellectuals who write in English." Somewhere else, the same introduction specifies the user's language when it refers to the fact that the dictionary was compiled "to serve the Arab youth" although the dictionary was originally written for Orientalists and English-speaking learners of Arabic. Also, in the introduction to the Learner's Dictionary there is a reference to the learner, without specifying his native language. This piece of information is given cursorily at the point where the transliteration system is described. A more transparent preface is found in the Dictionary of Modern Written Arabic which indicates that the dictionary will be positively received by British and American users as well as Orientalists worldwide. It also refers to the activities in which the dictionary would be most useful, i.e. handling texts written at the beginning of this century. However, it refers cursorily to the Arab user in another section where it describes the microstructure of entries. This is despite the author's awareness that it would be difficult for Arab users to locate the required information in a dictionary primarily designed for Westerners who read or translate from Arabic and not for Arabs writing in or translating into English. Arab users will, in the first place, face the problem of synonym accumulation without enough sense discrimination (Kromann et al. 1984).

In the other two dictionaries, the School Dictionary and Elias' Modern Dictionary, the Arab compilers address foreign in addition to Arab users for whom these dictionaries were designed. Thus each dictionary contains a pair of introductions, one written in Arabic, the other in English. In the school dictionary, the Arabic introduction says that the dictionary is aimed at students of English at Egyptian and other schools in the Arab East. The English introduction of the same dictionary addresses speakers of English by saying that "this dictionary is primarily aimed at meeting the needs of Arabic speakers in their study of the 
English language but in many aspects it will be found useful by English speaking students of Arabic who attained an advanced level in their studies". The introduction of Elias' Modern Dictionary clearly indicates both user groups. Its compiler says that his dictionary had been designed for both groups: the Westerner who suffers from expensive and bulky dictionaries and the Arab user for whom no similar dictionary has been written before. He alleges that Arab students of English do not benefit from Orientalists' dictionaries. In his English introduction, he emphasizes the need for an Arabic-English dictionary that helps the foreigner to read modern publications such as newspapers.

The exception here is Al-Mawrid, which specifies one user group but without reference to their educational level or the activities in which the dictionary should be used. The compiler specifies Arab users as the targeted group when he says that the dictionary aims "to save the Arab user the trouble of referring to English dictionaries". Somewhere else, at the point where scientific terms are addressed, he identifies this Arab user as the educated Arab.

\subsection{Reference to the reasons for compiling the dictionary}

Most lexicographers tend to use the introduction for explaining the reasons behind their compilations. However, these explanations vary enormously, from an objective view of EFL learners' linguistic needs to an emphasis on flexibility in acceptance of new and foreign words in Arabic.

The introduction of the $O A L D$ focuses on the theoretical foundation established by Hornby that EFL learners need dictionaries which differ from those designed for native speakers of English, especially for comprehension and composition. The users' needs are also cited in the bilingual dictionary CollinsRobert. Its introduction indicates that the dictionary aims to provide the user with the highest levels of linguistic competence coupled with ease of use.

The introductions of Orientalists' dictionaries usually discuss the increasing interest in Arabic and tend to provide justifications for listing dialect words which are treated as part and parcel of modern Arabic. In the Dictionary of Modern Written Arabic, the introduction speaks about the growing interest in bilingual dictionaries of Arabic as the motive behind the compiler's decision to translate his Arabic-German dictionary into English. Also, it provides an analysis of written Arabic which has standard morphology and syntax in all Arab countries, emphasizing the fact that Arabic dialects and foreign words, especially in scientific and technological fields, have had considerable influence on the Arabic language. It also indicates that the dictionary follows a descriptive approach by referring to modern Arabic publications which constitute the corpus. The last dictionary in this group, Wortabet's Dictionary, refers in its introduction to the increasing role of English by saying that "the management at Librairie du Liban decided to offer this precious work of reference to the Arab World where the numbers of English students are increasing constantly".

As for bilingual dictionaries compiled by Arab lexicographers, the empha- 
sis in their introductions is always on translation and the need to write a dictionary specifically for Arab users, taking into account their different reference skills. The introduction to Al-Mawrid contains the compiler's personal observations on his work in English-Arabic translation in which he relied on old dictionaries dating back to the years 1911 and 1913 and the early 1950s. These works were found unsatisfactory vis-à-vis the translator's needs, thus forcing him to refer to English monolingual dictionaries. He also indicates the need to translate scientific terms, saying: "Modern scientific terms are sought by most English-Arabic dictionaries but their absence is more noticeable than other types of words ... Specialized dictionaries provide the technical term without any explanation." The compiler adds another essential aim: writing a comprehensive dictionary that provides the largest number of vocabulary items, thus emphasizing the function of this dictionary as a translation tool.

Elias' Modern Dictionary presents similar reasons in addition to the compiler's opinion about the inclusion of what he calls "contemporary or living vocabulary". The introduction outlines a number of reasons behind the compilation. The first was the desire to meet the Arab learner's need for learning the English equivalents of living Arabic words and the lack of an Arabic-English dictionary. Secondly, Orientalists' dictionaries give explanations which are of interest only to students of classical Arabic, e.g. plurals, verb conjugations, feminine and masculine forms and archaic words, all of which may distract the Arab user. Thirdly, there is the difficulty of using Arabic dictionaries which require their users to know word roots. As fourth reason he mentions the noninclusion of contemporary Arabic vocabulary in older dictionaries, citing the fact that language is similar to a living organism that grows and changes over the years. Accordingly, he calls for flexibility in accepting new words used in newspapers and scientific publications and welcoming those words which find favour with the Arabs.

\subsection{Reference to the sources of the dictionary}

The introductory matter usually refers to the sources used in the process of collecting the material for the dictionary. This would make users aware of the variety of vocabulary, the extent of lexical comprehensiveness, and the accuracy of definitions or translation equivalents. The analysis of the eight introductions has revealed that three of them do not include any reference to the sources of the dictionary nor the collection of material. The sources of the other dictionaries ranged between computerized corpora for written and spoken forms of language consisting of tens of millions of lexical items to newspapers, periodicals, translated works and dictionaries of different types.

The introduction to the $O A L D$ informs the user that the lexicographic team relied on the British National Corpus which helped them to determine the relative frequency of words and collocations, to confirm new words, to check the 
accuracy of syntactic structures and to rewrite many illustrative examples and add 9000 new example sentences. This description is obviously meant to tell the users that they can rely on the accuracy and comprehensiveness that characterize the computerized selection and arrangement of dictionary material. Introductions in Orientalists' dictionaries vary with regard to this element, depending on whether the dictionary is the result of team work or individual effort. In the Dictionary of Modern Written Arabic, the compiler indicates that he relied on a corpus of primary source materials of selected works by Taha Hussain, Muhammad Hussain Haikal, Taufiq al-Hakim and Mahmud Taimur, and numerous newspapers and periodicals in Egypt and Iraq. The secondary sources include different dictionaries such as Elias' Modern Dictionary and other bilingual dictionaries of Arabic and French, and Hebrew and Russian for comparison with the dictionary's wordlist. Also, Webster's International Dictionary is referred to as an authority on spelling and definitions. However, the introduction does not specify many works used as secondary sources; it only refers to them in general terms, i.e. a number of reference works in European languages, encyclopedias, lexicons, glossaries, technical dictionaries, and specialized literature. These were used to ascertain the correct translation of many technical terms. Reference to these sources occupies a large section of the introduction and shows to some extent the compiler's observance of copyright. Yet, according to modern practice, lexicographers tend to allocate a separate page to list the sources of the dictionary.

Wortabet's Dictionary, the result of an individual effort, refers in its introduction to its sources which are bilingual dictionaries only. It focuses on a comparison with Lane's Arabic-English dictionary. The aim of giving this information might be to imply that the new dictionary is not inferior in quality and comprehensiveness to older Arabic-English dictionaries. In the introduction to the bilingual Learner's Dictionary there is a brief reference to the sources of English words. These are translated works such as the Quran and Arabian Nights, which give the impression that the vocabulary is of a classical nature and on a highly rhetorical level.

Two of the introductions to the bilingual dictionaries compiled by Arab lexicographers do not give any information on the dictionary's sources nor on the process of collecting the material. The compiler of Al-Mawrid speaks about the fact that his dictionary was the result of comparing existing English-Arabic dictionaries with English monolingual ones in order to determine the missing vocabulary items, and of referring to specialized dictionaries, the terminology compilations of the Arabic Language Academy in Cairo, and Arabized scientific books. Not only were lexical items taken from these sources but also illustrative examples. A list of sources is given on a separate page, thus conforming to modern practice in dictionaries although no indication is given as to whether permission has been obtained from authors or publishers to use the listed sources. 


\section{Conclusions}

To sum up, the present study has found:

(a) The dictionaries examined here vary in the extent to which their user groups are specified in the introduction. Some dictionaries refer in broad terms to several groups with different reference needs while others specify one group such as learners but without indicating their mother tongue or the activities for which the dictionary may be used, e.g. writing, reading, or translating from or into a foreign language.

(b) The European dictionaries (OALD and Collins-Robert) designed for learners or translators address the reasons for compilation and relate them to users' needs whereas the Orientalists' bilingual dictionaries focus in their explanations on the need for dictionaries that contain dialect Arabic vocabulary in addition to the standard variety. The bilingual dictionaries compiled by Arab lexicographers base their explanations on the needs of translators and learners and the inadequacy of Arabized technical terms.

(c) Most of these dictionaries (five out of eight) acknowledge their sources which range between computerized corpora and newspapers, periodicals, translated works and dictionaries of different types. However, some dictionaries are not specific in their reference to their source dictionaries and do not indicate whether permission has been obtained from their compilers or publishers.

(d) The compilers of the dictionaries examined (except for Collins-Robert and the Learner's Dictionary) claim their dictionaries to be superior to similar dictionaries by focusing on parameters such as accuracy, comprehensiveness of lexical coverage, and ease of use.

(e) In the most recent dictionaries, e.g. OALD and Collins-Robert, the introductions concentrate on the new features in the dictionaries, reflecting an increasingly competitive dictionary market.

(f) The compilers of the modern dictionaries in this study pay special attention to the indication of the number of entries (or words) in their dictionaries to emphasize the lexical comprehensiveness and usefulness of the dictionaries in reading or translating foreign language texts.

(g) The compilers of OALD and Collins-Robert emphasize in their introductions the fact that the material was selected with the help of computerized corpora whereas the introductions in the Orientalists' bilingual dictionaries indicate the descriptive approach followed in selecting Arabic 
words including dialect vocabulary. The introductions of Arab compilers' bilingual dictionaries stress the role of the dictionary as a translation tool and, therefore, emphasize the use of standard Arabic as the language of translation equivalents, excluding obsolete words and paying special attention to the inclusion of Arabized scientific terms.

\section{Acknowledgments}

This study was supported by Kuwait University research grant no. AE01/00.

\section{References}

\section{A. Dictionaries}

Atkins, B.T. 1996. Collins-Robert: French-English/English-French Dictionary. Glasgow/Paris: D. le Robert-Collins.

Baalbaki, M. 1998 (1967). Al-Mawrid: A Modern English-Arabic Dictionary. Beirut: Dar el-Ilm LilMalayin.

Crowther, J. 1995. Oxford Advanced Learner's Dictionary. Oxford: Oxford University Press.

Elias, A. 1991 (1922). Elias' Modern Dictionary: Arabic-English. Beirut: Librairie du Liban.

Elias, E. 1964. The School Dictionary: Arabic-English. Beirut: Dar al-Jeel.

Steingass, F. 1989. A Learner's Arabic-English Dictionary. Beirut: Librairie du Liban.

Wehr, H. 1995 (1966). A Dictionary of Modern Written Arabic. Wiesbaden: Otto Harrasowitz.

Wortabet, W.T. 1984. Wortabet's Arabic-English Dictionary. Beirut: Librairie du Liban.

\section{B. Other references}

Atkins, B.T. 1985. Monolingual and Bilingual Learners' Dictionaries: A Comparison. Ilson, R. (Ed.). Dictionaries, Lexicography and Language Learning: 15-24. Oxford: Pergamon Press.

Béjoint, H. 1981. The Foreign Student's Use of Monolingual English Dictionaries: A Study of Language Needs and Reference Skills. Applied Linguistics 2(3): 207-222.

Berkov, V.P. 1990. A Modern Bilingual Dictionary — Results and Prospects. Magay, T. and J. Zigany (Eds.). 1990. BudaLEX '88 Proceedings: 97-106. Budapest: Academiai Kiado.

Cowie, A.P. 1987. Syntax, the Dictionary and the Learner's Communicative Needs. Cowie, A.P. (Ed.). The Dictionary and the Language Learner: 183-192. Tübingen: Niemeyer.

Crystal, D. 1986. The Ideal Dictionary, Lexicographer and User. Ilson, R. (Ed.). Lexicography: An Emerging International Profession: 72-81. Manchester: Manchester University Press.

Gimson, A.C. 1973. Phonology and the Lexicographer. McDavid, R. and A. Duckert (Eds.). Lexicography in English: 115-121. New York: The New York Academy of Sciences.

Hartmann, R.R.K. 1986. The Training and Professional Development of Lexicographers in the UK. Ilson, R. (Ed.). Lexicography: An Emerging International Profession: 89-92. Manchester: Manchester University Press. 
Hartmann, R.R.K. 1987. Four Perspectives on Dictionary Use: A Critical Review of Research Methods. Cowie, A.P. (Ed.). The Dictionary and the Language Learner: 11-28. Tübingen: Niemeyer.

Householder, F.W. and S. Saporta. 1962. Problems in Lexicography. Bloomington: Indiana University Press.

Kromann, H., T. Riider and P. Rosbach. 1984. "Active" and "Passive" Bilingual Dictionaries: The Sčerba Concept Reconsidered. Hartmann, R.R.K (Ed.). LEXeter '83 Proceedings: 207-215. Tübingen: Niemeyer.

Rossner, R. 1985. The Learner as Lexicographer: Using Dictionaries in Second Language Learning. Ilson, R. (Ed.). 1985. Dictionaries, Lexicography and Language Learning: 95-102. Oxford: Pergamon Press.

Snell-Hornby, M. 1987. Towards a Learner's Bilingual Dictionary. Cowie, A.P. (Ed.). The Dictionary and the Language Learner: 159-170. Tübingen: Niemeyer.

Stein, G. 1984. Towards a Theory of Lexicography: Principles and/vs. Practice in Modern English Dictionaries. Hartmann, R.R.K. (Ed.). LEXeter' 83 Proceedings: 124-130. Tübingen: Niemeyer.

Stein, G. 1989. Recent Developments in EFL Dictionaries. Tickoo, M. (Ed.). Learners' Dictionaries: State of the Art: 72-83. Singapore: SEAMEO Language Centre.

Wiegand, H. 1984. On the Structure and Contents of a General Theory of Lexicography. Hartmann, R.K.K. (Ed.). LEXeter '83 Proceedings: 13-28. Tübingen: Niemeyer. 